\title{
PARATHYROID GLANDS AUTOTRANSPLANTATION: WHY? WHEN? HOW?
}

\author{
TOMISLAV NOVOSEL ${ }^{1}$, PETER JECKER1, VLADIMIR BEDEKOVIĆ², DRAGO BOŠČIĆ \\ TOMISLAV ŠUSNJAR ${ }^{3}$ and JOSEPH SCHARPF ${ }^{4}$ \\ ${ }^{1}$ Department of Otolaryngology and Plastic, Head and Neck Surgery, Klinikum Bad Salzungen, GmbH, \\ Bad Salzungen, Germany; \\ ${ }^{2}$ Department of Otorhinolaryngology and Head and Neck Surgery, Sestre milosrdnice \\ University Hospital Center, Zagreb, Croatia; \\ ${ }^{3}$ Department of Otorhinolaryngology and Head and Neck Surgery, University Hospital Dubrava, \\ Zagreb, Croatia; \\ ${ }^{4}$ Department of Otolaryngology, Cleveland Clinic, Cleveland, Ohio, United States of America
}

\section{Summary}

Parathyroid glands produce parathyroid hormone (PTH), which regulates calcium level in peripheral circulation by controlling calcium relocation and calcium excretion. Hypoparathyroidism is one of the potential complications that can occur during thyroid surgery. Hypocalcemia, as a result of hypoparathyroidism, can cause severe symptoms, even lifethreatening, when not treated properly.

In this paper, we would like to focus on how to preserve the function of the parathyroid glands during thyroid surgery and prevent transient and permanent hypoparathyroidism by opting to perform parathyroid autotransplantation. To structure our suggestion, we divided the article into why, when, and how to do the parathyroid autotransplantation?

KEYWORDS: parathyroid gland, parathyroid auto-transplantation, hypoparathyroidism, hypocalcemia

\section{AUTOTRANSPLANTACIJA PARATIREOIDNIH ŽLIJEZDA: ZAŠTO? KADA? KAKO?}

\section{Sažetak}

Paratireoidne žlijezde stvaraju paratireoidni hormon (parathormon, PTH) koji regulira koncentraciju kalcija u krvi kontrolirajući preraspodjelu i izlučivanje kalcija. Hipoparatireoidizam je jedna od komplikacija koja se može razviti prilikom operacije štitne žlijezde. Hipokalcijemija kao posljedica hipoparatireoidizma može izazvati ozbiljne znakove, čak i one opasne po život, ukoliko se odgovarajuće ne liječi.

U ovom radu želimo prikazati kako očuvati i provjeriti funkciju paratireoidnih žlijezda za vrijeme operacije štitne žlijezde te spriječiti privremeni i trajni hipoparatireoidizam odlučujući je li potrebno auto-transplantirati paratireoidnu žlijezdu ili ne. Zbog jednostavnijeg prikaza podijelili smo pristup u tri dijela: zašto, kada i kako auto-transplantirati paratireoidne žlijezde?

KLJUČNE RIJEČI: paratireoidna žlijezda, auto-transplantacija paratireoidnih žlijezda, hipoparatireoidizam, hipokalcijemija 


\section{WHY?}

Permanent hypoparathyroidism is a debilitating morbidity after thyroid surgery, with the incidence of $0 \%$ to $3 \%(1)$. These values probably underestimate true prevalence because of the incomplete follow up and the lack of clear definitions. Parathyroid autotransplantation is effective in reducing permanent hypoparathyroidism. The majority of auto transplanted grafts work consistently after the surgery (2). Due to the rate of successful parathyroid auto-transplantation, there was a suggestion to perform routine elective parathyroid auto-transplantation of at least one parathyroid gland in all patients undergoing thyroid surgery. The routine autotransplantation would minimize the risk of permanent hypoparathyroidism to almost $0 \%$ (3). However, routine parathyroid autotransplantation increases the risk of transient hypoparathyroidism. Thus, there is a need for a tailored approach to parathyroid auto-transplantation to drive the rate of permanent hypoparathyroidism to $0 \%$, while markedly reducing the incidence of transient hypocalcemia.

\section{WHEN?}

During thyroid surgery, it is crucial to identify and preserve parathyroid glands, as well as the function of the recurrent laryngeal nerve. Surgical skill and experience play essential roles in the management of the parathyroid glands. It is essential not only to identify the parathyroid glands but also to recognize if the parathyroid glands are injured and to determine if the parathyroid glands can recover and eventually function normally. A compromise in blood supply, for example, can result in necrosis and loss of function.

The following mechanisms of parathyroid injury have been identified:

1. Inadvertent removal (failure to identify parathyroid glands increases risk),

2. Mechanical or thermal trauma (hematoma formation and secondary necrosis),

3. Gland devascularization (lack of arterial inflow or surrounding inflow, venous outflow obstruction),

4. Radical resection with oncologic considerations (central neck dissection implications),
5. Unfavorable gland position (high on gland with no discernible pedicle, recurrent laryngeal nerve consideration).

There are several ways to assess the viability of the parathyroid glands regarding their underlying vascular supply. A simple and practical test is the knife test. We cut a small area of parathyroid to assess bleeding and prove the viability of circulation in the parathyroid gland, analogous to testing the condition of a reconstructive flap. Alternatively, the lidocaine test is a useful and cost-effective method for assessing the parathyroid gland's viability during thyroid surgery. When we apply topical lidocaine to a compromised parathyroid gland, it can cause a microvascular dilation with the return of turgor, color, and bleeding to needle prick test of the gland (4).

Another test uses intraoperative micro-ultrasound probes with a color-doppler examination to determine the blood flow of the parathyroid gland and thus prove if the circulation in the examined parathyroid gland is compromised or not.

Finally, intraoperative measurements of the PTH level can be a useful method in the assessment of the viability of the parathyroid glands. Because the median half-life of parathyroid hormone is only 3 minutes long, this functional assessment of using parathyroid hormone in the peripheral circulation during the surgery can be used to great advantage (5).

M. Barczynski and al. performed a study on the applicability of intraoperative parathyroid hormone (IOPTH) assay during total thyroidectomy as a guide for the surgeon to perform selective parathyroid tissue auto-transplantation. Three hundred and forty patients were randomized to elective parathyroid auto-transplantation of at least one gland or selective intra-operative parathyroid hormone-guided parathyroid auto-transplantation (iPTH<10 ng/L).

No patients suffered from permanent hypoparathyroidism. In the group of patients that underwent elective parathyroid auto-transplantation, $22.3 \%$ of the patients had transient hypoparathyroidism versus $11.2 \%$ of the patients with transient hypoparathyroidism in the IOPTHguided group. Selective IOPTH-guided parathyroid testing decreased the incidence of transient postoperative hypoparathyroidism, and autotransplantation was an effective strategy to prevent permanent hypoparathyroidism (6). 
Another critical study was performed by R. Promberger al. The goal of the study was to assess parathyroid discoloration as a loss of function. They identified three groups of patients: Group A $(n=12)$ with four visualized and normal colored parathyroid glands, Group B ( $n=13)$ with four visualized and 3 to 4 severely discolored (black) parathyroid glands and Group C $(n=4)$ patients that underwent parathyroid auto-transplantation of two parathyroid glands. Blood was sampled 10 minutes after resection of the first and the second thyroid lobe, 3 hours after the operation and postoperative days 1,2,3. All inadvertently removed parathyroid glands were auto-transplanted. Parathyroid glands were preserved when blood supply was estimated to be maintained by a strong vessel pedicle, delicate pedicle, and vascularized connective tissue or vessels from thyroid remnant. The results showed that damaged parathyroid glands frequently recover. PTH secretion levels tended to reach normal levels within the first days after surgery. The PTH secretion was reduced in patients with auto-transplantation of two parathyroid glands, and the process of normalization took longer if the surgeon decided to auto-transplant in comparison to leaving even a discolored parathyroid gland in situ. It is important to note that arterially-compromised, de-vascularized or removed parathyroid glands do not become discolored but rather pale in appearance.

Therefore, a recommendation for preserving discolored parathyroid glands in situ, when blood supply was preserved with a strong vessel pedicle, delicate pedicle, vascularized connective tissue, or vessels from thyroid remnant (7).

L. Lorente-Poch and al. further investigated the importance of in situ preservation of parathyroid glands during total thyroidectomy. During the study, they established a scoring system to define the status of the parathyroid glands in aggregate. The score consists of the number of parathyroid gland remaining in situ (PGRIS), i.e., PGRIS= 4 - (glands auto-transplanted + glands in the $\mathrm{s}$ mean that all glands in the specimen). For example, a PGRIS score of 4 would mean that all glands remained in situ. Six hundred fifty-seven patients were included. All of them underwent total thyroidectomy, PGRIS group 1-2, included 43 patients, PGRIS 3 had shown that in situ, parathyroid preservation was critical in preventing permanent hypoparathyroidism (8).
The critical question regarding auto-transplantation of the parathyroid glands is, does the number of glands transplanted affect the outcome? In other words, what is the incidence of temporary and permanent hypoparathyroidism? An increased incidence of temporary hypoparathyroidism has been shown in cases when an increased number of glands had been transplanted. The same study showed no effect on long-term outcome of permanent hypoparathyroidism, and recommendation for a ready selective approach was put forth (9).

An innovative approach of thyroid surgery regarding parathyroid glands may involve the use of autofluorescence of parathyroid glands in realtime. Using this method, surgeons apply near-infrared laser light to analyze the intensity of the fluorescence of parathyroid glands and thyroid glands. The autofluorescence of thyroid and parathyroid glands are of different intensity, thus allowing the surgeon to identify parathyroid glands (10).

Controversy exists regarding the management of the inferior parathyroid glands in patients with thyroid cancer afflicted with regional central lymph node- the metastases that would require central neck dissection. It is crucial to find a balance between comprehensive neck dissection and the protection of the parathyroid glands. Ultimately, long term function and the best oncologic outcome are of the highest importance. They compared the incidence of postoperative hypoparathyroidism and central neck lymph node recurrence in patients with inferior parathyroid autotransplantation (321 patients) versus preservation in situ ( $\mathrm{n}=156$ patients). The study showed that auto-transplantation of the inferior parathyroid gland during central neck dissection provided a lower incidence of permanent hypoparathyroidism $(0.9 \%$ vs. $3.8 \%)$ and central neck lymph node recurrence $(0.3 \%$ vs. $3.8 \%)(11)$.

\section{HOW?}

The technique of auto-transplantation is important. An important first step to perform the auto-transplantation is to perform a frozen section analysis to see when possible to confirm that tissue is something that should be auto-transplanted. It is critical to exclude malignant diseases such as metastatic lymph nodes that may mimic para- 
thyroid tissue or even the sporadic parathyroid carcinoma. The strategy for auto-transplantation of a parathyroid gland is established. First, it is essential to increase the surface area of the gland by cutting the gland with a blade to $1 \times 3 \mathrm{~mm}$ pieces (1). The next step should be to immediately autotransplantation into the muscle (ipsilateral or contralateral sternocleidomastoid muscle, or any muscle that is intact in a possible subsequent radical neck dissection, i.e., trapezius muscle or brachioradialis muscle of non-dominant arm). The last step should be to re-approximate the muscle pockets with radio-opaque metal clips or longtailed non-absorbable monofilament sutures (aids in graft localization in case of a re-operation).

Another described option is the intramuscular injection of parathyroid autografts. In one of the studies, 66 patients were divided into two groups, with total parathyroidectomy for renal hyperparathyroidism. In the first group, the implant group $(\mathrm{n}=31)$ was treated with $10-122 \mathrm{~mm}$ pieced into deltoid or brachioradialis muscle, and the second group, injection group $(n=35)$ - intramuscular injection into deltoid. Grafts functioned in $87.1 \%$ in the implant patients and in $69 \%$ in the injection patients $(\mathrm{p}=0,08)$.

Hyperparathyroidism recurrence was $12.0 \%$ in the implant patients vs. $2.9 \%$ by in the injection patients. Therefore, intramuscular injection becomes a feasible alternative (12). Parathyroid glands can also be cryopreserved, and a delayed auto-transplantation is accepted.

Indications for this procedure include: patients after initial neck operation with high risk for permanent postoperative hypoparathyroidism, patients after subtotal(3.5), near-total, or total parathyroidectomy, patients with multiple gland hyperplasia, familial or hereditary $\mathrm{PHPTH}$, secondary and tertiary hyperparathyroidism (renal), for patients after re-operative neck procedures and for patients with specific scenarios (i.e., radical neck dissection) (13). The controversy remains regarding whether or not this auto-transplantation method of the parathyroid glands is successful. In one study, 2083 patients treated from 2001 to 2010 underwent parathyroidectomies for hyperparathyroidism. Twenty-one percent $(n=442)$ of the samples underwent cryopreservation, and four patients $(1 \%)$ underwent delayed auto-transplantation, $3 / 4$ remained hypoparathyroid. A single cured patient underwent the procedure only four days after initial parathyroidectomy. Because of the reported results, it is questionable if cryopreservation is feasible and useful (14).

\section{DISCUSSION}

The devastating morbidity in patients suffering from permanent hypoparathyroidism remains a serious concern to all head and neck endocrine surgeons. Traditional approaches to re-implantation of normal parathyroid tissue have alleviated this morbidity dramatically. On the other hand, the cost of an increase in transient hypoparathyroidism, which is significant morbidity, also for patients $(6,8)$. An investigation into the kinetics of parathyroid hormone and recovery of parathyroid function in glands that have been left in situ has revealed that parathyroid glands are quite resilient with regards to function after the operative intervention $(6,7,8)$. A recommendation was put forth for preserving discolored parathyroid glands in situ when blood supply was estimated to be maintained by a strong vessel pedicle, delicate pedicle, vascularized connective tissue, or vessels from thyroid remnant (7). This recommendation can be complemented with the surgical experience of the team and adjunctive measures such as Doppler examination of blood supply, turgor, and lidocaine testing (4), and intraoperative parathyroid hormone assay (6) if a gland is deemed nonviable. It is critical to increasing the surface area of the gland by mincing it, preferably after histologic confirmation that it is indeed parathyroid tissue and placing it in a well-marked pocket of vascularized tissue that would be accessible and at low risk of compromise if further surgery was warranted.

\section{CONCLUSION}

It is incumbent upon the surgeon to be wellversed in the methods of parathyroid auto-transplantation during thyroid surgery when parathyroid glands are inadvertently removed.

More importantly, however, is the surgeon's ability to critically evaluate parathyroid glands in situ to determine when there is a concern for the viability of the parathyroid glands. This recent surgical experience of subjective findings $(4,7)$ with tested, objective techniques $(5,6)$ analyzing 
the viability of the parathyroid glands in an intraoperative setting. The overarching goal remains a long term normal parathyroid function while minimizing transient hypoparathyroidism and the morbidity associated with it.

\section{REFERENCES}

1. Edafe O, Antakia R, Laskar N, Uttley L, Balasubramanian SP. Systematic review and meta-analysis of predictors of post-thyroidectomy hypocalcaemia. Br J Surg. 2014;101:307-20.

2. Olson JA Jr, DeBenedetti MK, Baumann DS, Wells SA Jr. Parathyroid autotransplantation during thyroidectomy. Results of long-term follow-up. Ann Surg. 1996;223:472-8.

3. Zedenius J, Wadstrom C, Delbridge L. Routine autotransplantation of at least one parathyroid gland during total thyroidectomy may reduce permanent hypoparathyroidism to zero. AZN J Surg. 1999;69:794-7.

4. Kuriloff DB, Kizhner V. Parathyroid gland preservation and selective autotransplantation utilizing topical lidocaine in total thyroidectomy The Laryngoscop. 2010;120:1342-4.

5. Leiker AJ, Yen TWF, Eastwood DC, Doffek KM, Szabo A, Evans DB et al. Factors that influence parathyroid hormone half-life: Are new intraoperative criteria needed? JAMA Surg. 2013;148:602-6.

6. Barczynski M, Cichon S, Konturek A, Cichon W. Applicability of intraoperative parathyroid hormone assay during total thyroidectomy as a guide for the surgeon to selective parathyroid tissue autotransplantation. World J. Surg. 2008;32:822-8.

7. Promberger R, Ott J, Kober F, Mikola B, Karik M, Freissmuth $\mathrm{M}$ et al. Intra- and postoperative parathyroid hormone-kinetics do not advocate for autotransplan- tation of discolord parathyroid glands during thyroidectomy. Thyroid. 2010;20:1371-5.

8. Lorente-Poch L, Sancho JJ, Ruiz S, Sitges-Serra A. Importance of in situ preservation of parathyroid glands durig total thyroidektomy. BJC. 2015;102:359-67.

9. Palazzo FF, Sywak S, Sidhu SB, Barraclough BH, Delbridge LW. Parathyroid autotransplantation during total thyroidectomy--does the number of glands transplanted affect outcome? World J. Surg. 2005;29:629-31.

10. Falco J, Dip F, Quadri P, de la Fuente M, Rosenthal R. Cutting Edge in thyroid surgery: Autofluorescence of parathyroid glands. J Am Coll Surg. 2016;223:374-80.

11. Wei T, Li Z, Jin J, Chen R, Gong Y, Du Z et al. Autotransplantation of inferior parathyroid glands during central neck dissection for papillary thyroid carcinoma: a retrospective cohort study. Int J Surg. 2014; 12:1286-90.

12. Tan CC, Cheah WK, Tan CT, Rauff A. Intramuscular injection of parathyroid autografts is a viable option after total parathyroidectomy. World J Surg. 2010; 34:1332-6.

13. Agarwal A, Waghray A, Gupta S, Milas M. Cryopreservation of parathyroid tissue: an illustrated technique using the Cleveland Clinic protocol. J Am Coll Surg. 2013;216:1-9.

14. Shepet K, Alhefdhi A, Usedom R, Sippel R, Chen H. Parathyroid cryopreservation after parathyroidectomy: A worthwhile practice? Ann Surg Oncol. 2013; 20:2256-60.

Corresponding author: Tomislav Novosel, Department of Otolaryngology and Plastic, Head and Neck Surgery, Am Lindig, 36433 Klinikum Bad Salzungen, GmbH, Bad Salzungen, Germany. E-mail: novoseltomislav@yahoo.com 